\title{
sciendo
}

\section{METHODOLOGY FOR FORECASTING REVENUES FROM THE SALE OF INNOVATIVE PRODUCTS IN THE DOMESTIC TOURISM MARKET}

\author{
METODYKA PROGNOZOWANIA PRZYCHODÓW ZE SPRZEDAŻY PRODUKTÓW INNOWACYJNYCH
}

NA KRAJOWYM RYNKU TURYSTYCZNYM

\author{
Liudmyla Shulhina \\ University of Finance and Law \\ Czesława Tańskiego Street 5, 43-382 Bielsko-Biała, Poland \\ shulm@ukr.net 0 ORCID 0000-0001-9554-6185 \\ DOl: 10.2478/minib-2021-0016
}

\section{ABSTRACT}

This article presents a methodology for forecasting the expected sales of innovative tourism products in the domestic market. The principles of the product life cycle concept and consumer behavior theory are taken as starting points for calculating the sales volumes of an innovative product as well as the rate of its penetration into the market. A method of measuring the level of consumer commitment to a travel agency and its offerings is posited, and the relationship between the structure of the target market and market activity in purchasing tourist products is demonstrated. Deep market segmentation is applied to take into account the behavioral peculiarities of individual subsegments (Loyalists Market, Sympathizers Market, Qualified Market, Finders Market, Serviced Market, Possible Market, Potential Consumers Market, Perspective Market). Formulas are proposed for calculating the volume of each of the identified markets. An improved and adapted model for the tourist market (by E. Rogers and F. Bass) is used to calculate the diffusion rates of domestic tourist products. This methodology of forecasting the expected sales of innovative tourism products in the domestic market is empirically confirmed based on data on the domestic tourism market in the region of Vinnytsiya, Ukraine.

Key words: innovative products, tourism market product life cycle concept, consumer behavior theory, market subsegments, diffusion rate, Rogers and Bass model 


\section{ABSTRAKT}

W artykule przedstawiono metodykę prognozowania sprzedaży innowacyjnych produktów turystycznych na rynku krajowym. Koncepcję cyklu życia produktu i teorię zachowań konsumenckich przyjęto jako istotne punkty wyjścia do obliczania sprzedaży wolumenowej produktu innowacyjnego oraz tempa jego penetracji rynku. Zaproponowano metodę pomiaru poziomu lojalności konsumentów wobec biura podróży i zainteresowania jego ofertą. Analizowano związek między strukturą rynku docelowego a jego aktywnością w zakresie zakupu produktów turystycznych. Zastosowano głęboką segmentację rynku uwzględniającą specyfikę zachowań poszczególnych podsegmentów (Rynek Lojalistów, Rynek Sympatyków, Rynek Kwalifikowany, Rynek Poszukiwaczy, Rynek Obsługiwany, Rynek Możliwy, Rynek Potencjalnych Konsumentów, Rynek Perspektywiczny). Zaproponowano wzory do obliczania wielkości każdego z wyodrębnionych rynków. W artykule podano również przykłady wykorzystania modelu E.M. Rogersa i F. Bassa, odpowiednio dostosowanego do specyfiki rynku turystycznego, do obliczenia wskaźników dyfuzji krajowego produktu turystycznego. Metodologia prognozowania oczekiwanej sprzedaży innowacyjnych produktów turystycznych na rynku krajowym została potwierdzona empirycznie na podstawie danych dotyczących krajowego rynku turystycznego w regionie Winnicy na Ukrainie.

Słowa kluczowe: produkty innowacyjne, rynek turystyczny, koncepcja cyklu życia produktu, teoria zachowań konsumentów, podsegmenty, współczynnik dyfuzji, model E. Rogersa i F. Bass

JEL: JEL: Z33, M31

\section{Introduction}

An enterprise that is operating in a competitive environment always faces the problem of performance forecasting. At the same time, each change in market conditions that complicates the circumstances in which market players operate further exacerbates this problem, requiring continual updates to forecasting methods.

A number of previous studies have proposed indicators for forecasting future sales (Balashova \& Ivchenko, 2011; Dedu \& Saforo, 2016; Kirkova, 2014). In a previous study co-written by the present author (Shulgina \& Onishchuk, 2016), we focused on the dynamics of the diffusion of innovative tourism products in 2014-2016, prior to the pandemic brought by COVID-19. The toll this pandemic has had on the economies of the 
world, and especially on such vulnerable industries as tourism, prompted us to continue this research to cover the period of 2019-2020. Due to the pandemic, the flows of outbound and inbound tourism around the world have sharply decreased, which has forced travel agencies to intensify domestic tourism, in particular through the development of innovative tourist products (Global Business Travel, 2020).

\section{Objective and research methodology}

The aim of this article is to present an original methodology developed by the author to forecast the future sales of innovative tourist products, based on the concept of product life cycle and the theory of consumer behavior.

To develop this methodology, a set of methods drawn from both general theoretical and specific marketing research were employed. Methods of induction, deduction and system analysis were used for deep segmentation of the target market, which involved the separation of its subsegments to determine their specific characteristics: firstly, a theoretical analysis of the proposed classifications of structural elements of the market was performed, secondly, the proposed classification characteristics were systematized and thirdly, an improved original classification of target market subsegments was proposed.

The methods of comparison, survey, target, quota, and stratified selection were used to quantify the size of each share of the target market. Firstly, the assumptions of the product life cycle (PLC) concept and the theory of consumer behavior in terms of their attitude to innovation were combined. Secondly, a questionnaire was developed, which included sections to determine the characteristics of demand depending on the commitment of buyers to the travel agency and its offerings. Thirdly, on the basis of the developed questionnaire a survey was carried out, forming a targeted, quota-stratified sample of 538 clients of 17 travel agencies. Fourthly, the Statistics software package was used to analyze the obtained data.

Methods of grouping, comparison, statistical analysis were used to calculate the diffusion rate of domestic tourist products. The model of the 
tourist market proposed by Rogers and Bass was improved and adapted, in which the necessary coefficients were calculated based on official statistics and empirical data from travel agencies.

The research covered the tourist market in the region of Vinnytsia, Ukraine, in two periods: 1) the years 2014-2016; 2) the period of November 2019-June 2020

\section{Practical aspects of product life cycle theory and consumer behavior}

The concept of product life cycle begins with the observation that freshly developed (i.e. first offered this season) internal tourist products (TPs) are new for both the tourist agency (TA) and the tourism market. It follows that during the first few seasons after launching newly developed TPs, the peculiarities of their perception, and hence the speed and volume of sales will be influenced by the circumstances specific to new products. That is to say, at the "Introduction" stage there will be no competitors at all (if the TP is fundamentally new) or only very few of them. Sales volumes will grow slowly due to the inertia of consumers, and strong communication support is needed to accelerate them. Only "Super Leaders" will buy TPs - opinion leaders, a few of which are always present in the market (Husain, Ghufran \& Chaubey, 2016; Wozniak et al., 2018). The cash flow does not yet support any development costs, and profits are absent or insignificant. Over time, the market gradually begins to perceive the TP and the rate of its sales increases, which is indicative of the transition to the next stage.

The classical description of this stage in which a company brings an innovation to market is based on the analysis of a significant array of statistical data on the results of enterprises (i.e. as a generalization of past experience). At least three conclusions follow from this, which are very important for solving the following task of our study: predicting the duration and effectiveness of the stages of the PLC. First, the company will be interested in reducing the first stage and making the fastest possible transition to the second ("Growth"), because the stage of introducing a TP (like the prior stage of its development) requires investment, whereas 
returns are possible only in the next stages. Secondly, given indicators reflecting the structural characteristics of the target market, as well as the attitude of consumers to innovative TPs, it is possible for "anchor" agencies to determine their expected sales volumes. Thirdly, the level of consumer commitment to the TA (and therefore to its TPs) can be measured and, if necessary, adjusted using the marketing tools described above, regulating both the structure of the target market and its activity in purchasing of TP.

However, such forecasting on the basis of existing tendencies was found to be inexpedient, as these tendencies led to negative dynamics on practically all indicators reported by TAs of the Vinnytsia region. On the contrary, our goal is to change these trends to positive ones through the implementation of a proposed cooperative marketing system (Shulgina, 2005) program for TAs, following a systematic approach. The following sequence of steps was envisioned: determining of the structure and volume of Target Market (TM) and Serviced Market (SM); measuring the rate of diffusion of new TPs on the market; evaluation of alternative TPs and selection of them; calculation of additional revenues from the introduction of TPs.

\section{Constituent elements of the target market according to the level of consumer commitment to the given travel agency and its offerings}

Given that various researchers have different views on the structure and characteristics of the constituent subsegments of the target market as a common concept, in this section we present and justify the classification used herein.

Target Market (TM) - all the consumers who are targeted by the marketing complex.

Loyalists Market (LoyM) - consumers who have used the services of the given TA many times, fully trust the TP sales manager in terms of reliability, comfort, clear transport and other services.

Sympathizers Market (SympM) - consumers who have a positive attitude to both the TA and its TP; they trust the given TA and, avoiding taking risks, they do not look for alternatives, but rather seek to buy TPs 
from managers tested by previous experience; however, for various reasons (often due to financial constraints) they are not yet regular customers of this TA.

Qualified Market (QualM) - made up of the loyalists market and the sympathizers market - i.e. this is the market of non-random positiveminded customers of the TA, who are able to explain their choice to themselves and to the environment. Thus, the formula for calculating the $\mathrm{QM}$ is as follows:

QualM = LoyM + SympM.

Finders Market (FindM) - seekers of the best version of TPs, have no emotional attachment to either the TA or its TPs and are at the stage of comparing it with competitors. They make their choices either on the basis of a careful analysis of alternatives (usually choose the desired quality at the lowest price), or simply by coincidence.

Serviced Market (ServM) - this is the sum of qualified markets plus the finders market, which can be calculated by the formula:

ServM $=$ QualM + FindM $=$ LoyM + SympM + FindM.

Possible Market (PosM) - the portion of potential buyers who haven't yet bought TPs from this TA, but are already informed about its activities, are loyal to it, see the need for a specific TP and are considering buying it in the near future.

Potential Market (PotM) - this is the sum of the serviced and possible markets, which can be represented as the following formula:

PotM $=$ ServM + PosM $=$ LoyM + SympM + FindM + PosM.

Perspective Market (PerspM) - the whole market of potential consumers of TPs, including enterprises, companies, consumers that belong to the serviced and possible markets of other TAs, and which may become buyers of TPs under certain conditions.

Logically linking together the above definitions, we arrive at the following combined formula for determining the target market: 
$\mathrm{TM}=$ LoyM + SympM + FindM + PosM + PerspM.

A graphical illustration of the structure of the target market by the level of consumer commitment to the enterprise and its products is presented Fig. 1.

Fig. 1. Components of the target market by the level of consumer commitment to TA and TP

\section{Target Market}

Source: Miliutina, 2013a; Shulgina \& Miliutina, 2014.

Application of target market classification to the analysis of the structure of the respondents' sample

To empirically test the proposed model, we have chosen the market of high school and university students in the Vinnytsia region as the target market for a domestic TP. In the initial phase of the introduction of such a TP, taking into account its current quality, analysis should focus on the most unpretentious and most mobile consumers. Given the difficult sociopolitical situation in Ukraine, this requirement has become even more important. Based on data from Ukraine's statistical office (GUS, 2020) there are actually 957 general schools in the Vinnytsia region, with an average class size of 15.4 pupils. There are 157,000 pupils in the region, including 74,000 pupils of grades $7-11$. Technical education in the region is provided by 36 educational institutions, to 18,000 pupils.

There are 50 universities in the region with a total number of students of 43,000 . Thus, Vinnytsia alone (excluding neighboring regions) is able to 
provide a minimum $\mathrm{TM}=99,000$ people (counting $50 \%$ of school pupils and $100 \%$ of university students) and $\mathrm{SM}=33,000$ people. According to the pilot survey, the share of tourist-active youth is $48-55 \%$ among students and 30-35\% among working people. However, in view of data from Vinnitsia City Council (2019) and unfavorable situation for tourism, we adopted the lower limit for the SM - i.e. 1/3 of the TM. As the basis for determining the structure of the TargM and ServM of the internal TP, we took the results of research by Miliutina (2013b), adjusting them based on our data on the results of the survey (Tab. 1).

Notes:

1 - according to data from Vinnitsia City Council (2019), the TM is at least three times larger than SM, while according to the results of research (Miliutina, 2013b),

$\mathrm{TM}=$ LoyM + SympM + FindM + PosM + PerspM.

2 - according to data from Vinnitsia City Council (2019), 100\% of consumers amounts to 32,976 individuals (i.e. almost 33,000 people), which in our view represents the serviced market (ServM) for TA:

ServM $=$ LoyM + SympM + FindM.

Agreeing with the psychographic characteristics of certain segments, we explain that in our case, "Super Leaders" and "Leaders", who belong to the market of loyal consumers, are largely representatives of initiative groups, as well as involved school staff and leaders of student groups. It is possible that among the "Leader-Followers" and the "Moderate Majority" there may also be active parents of students and teachers, who should not be overlooked during the implementation of the program of education and communication activities. A significant part of the reference communication groups of the newly mentioned segments may also be included among the "Traditionalists".

Based on the fact that the "anchor" TA at this stage implements the strategy of "focusing", all their efforts should be focused on the first three segments of the Target Market, namely on the Serviced Market (i.e. the sum of Loyalists Market, Sympathizers Market and Finders Market).

The features of the selected segments, which will depend on the effectiveness of the derivation of TP, need to be taken into account: 


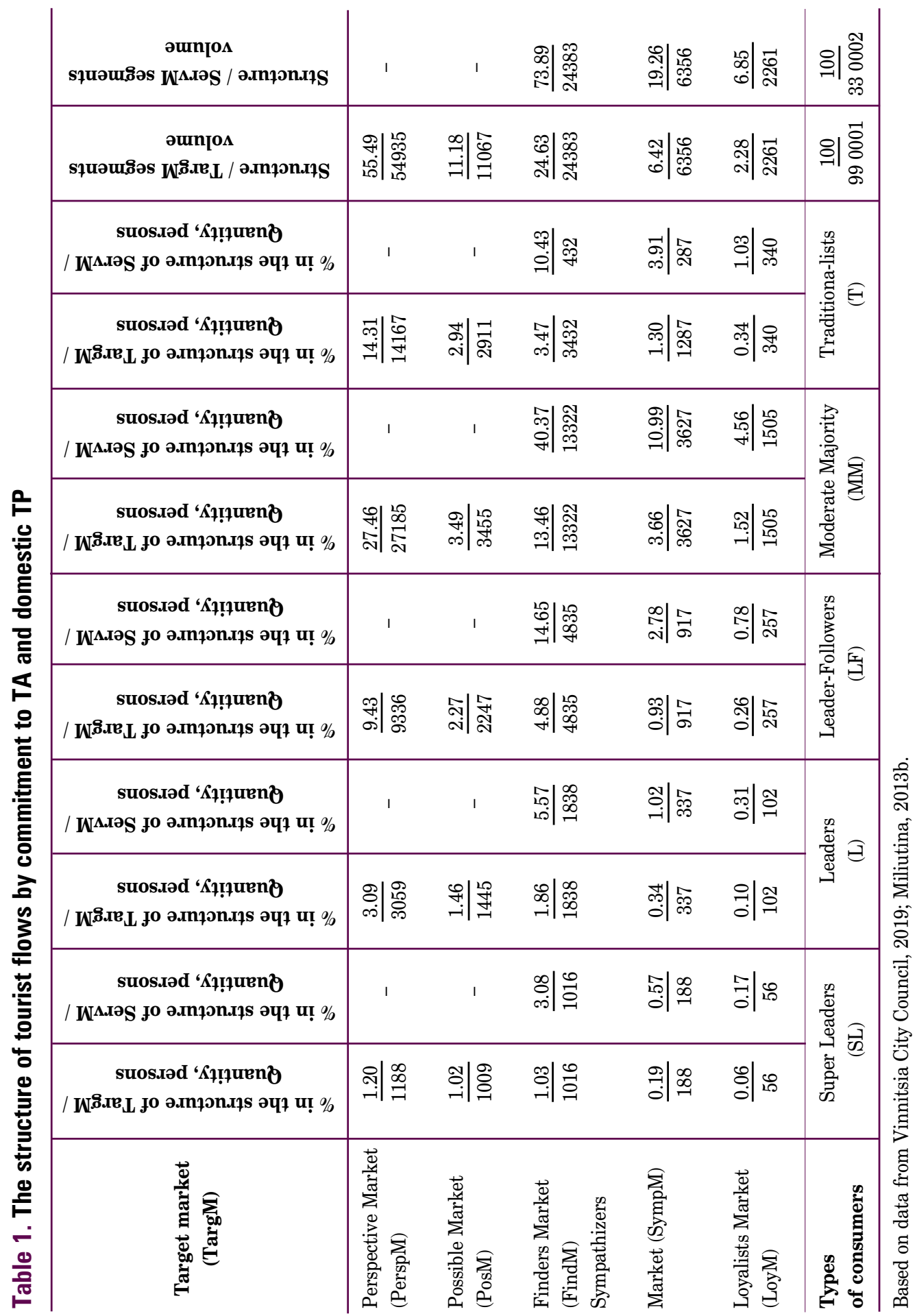


- The minimum shares of "Super Leaders" and "Leaders" are assumed due to the high level of risk of purchasing domestic TPs under modern conditions. However, as positive information on the TA and TP spreads, and in tandem with the improvement of the domestic political and economic situation in Ukraine, these shares should increase, as the cost of this type of TP is insignificant.

- The probability of a positive perception of the TP by other segments depends much more on the "Super Leaders" and "Leaders" segments in tourism (compared to other industries). This is due to the characteristics of the TP, the increased risk of its consumption, the speed of impact on the reference groups of social networks.

- The "Loyalists Market" segment is the smallest and the most difficult to cultivate and maintain, so to create a kind of "reserve" to replenish it, this is necessary to constantly work on expanding the "Sympathizers Market" and "Finders Market" groups. At the same time, it is necessary to take into account the much higher probability that consumers may transition to the "Loyalist Market" from the "Sympathizers Market" than from the "Finders Market".

- The volume of the most unstable segment of the "Finders Market" significantly exceeds the size of other segments and largely depends on the psychographic characteristics of its participants. The desire of consumers to "be a TP seeker" is explained, on the one hand, by the significant number of TAs in the market (which gives the impression of choice), and on the other - by the low quality of service (which creates a desire to find the expected "price-quality" ratio).

- The segment of "Traditionalists" is relatively small. However, firstly, it is almost comparable in number with the segment of "LeaderFollowers" (whose significant influence on the perception of TPs by the market is explained by their name), and secondly, "Traditionalists" significantly outperform "Leader-Followers" in terms of demand and commitment to priorities.

These features are also valid for consumers of inbound TPs, to which we initially considered to include foreign students studying in Ukraine. A pilot survey, however, showed that foreign nationals, who recently were sympathetic to Ukrainian TPs, consider visiting our country quite risky 
now and are even canceling previously scheduled visits. At the same time, those students who are currently studying at Ukrainian universities are more positive about the possibility of traveling within Ukraine. However, compared to local students, their share has been virtually halved, so we took the figure of $15 \%$ (1/2 of $30 \%)$. We feel that this category of consumers may become, firstly, an indicator for measuring the assessment of local TP by inflows, and secondly, a necessary communication bridge to promoting domestic Ukrainian TPs among foreign audiences.

These findings point to the need to develop individualized marketing in the activities of the "anchor" TA, which would take into account the characteristics of the described consumer segments. Of course, it is impossible for this to be done by one individual enterprise, however, in the event a cooperative marketing system is introduced, the TA will gain access to the required database and to specialists of with appropriate qualifications.

The measurement of the diffusion rate of the new TP to the market. The next step towards solving this problem is to measure the rate of diffusion of the new TP to the market. Here, an improved and adapted model of the tourist market (E. Rogers and F. Bass) was used to calculate the diffusion rates of domestic and inbound TP (Bass, 2014; Miliutina, 2013):

$$
\begin{aligned}
& \mathrm{n}(\mathrm{t})=\left(\mathrm{p} \times(\mathrm{M}-\mathrm{N}(\mathrm{t}))+\left(\mathrm{k} \times \frac{\mathrm{N}(\mathrm{t})}{\mathrm{M}} \times(\mathrm{M}-\mathrm{N}(\mathrm{t}))+\left(\mathrm{r} \times \frac{\mathrm{N}_{1}(\mathrm{t})}{\mathrm{M}} \times(\mathrm{M}-\mathrm{N}(\mathrm{t}))\right.\right.\right. \\
& \left.\mathrm{N}_{1}(\mathrm{t})\right)=(\mathrm{M}-\mathrm{N}(\mathrm{t})) \times\left(\mathrm{p}+\frac{\mathrm{r} \times N_{1}(t)}{M}\right)+\frac{\mathrm{k} \times N(t)}{M}-\mathrm{r} \times \frac{N_{1}^{2}(t)}{M}
\end{aligned}
$$

where, $\mathrm{n}(\mathrm{t})$ - quantity of consumers who accepted an innovation during the period $(\mathrm{t})$;

M - market potential (the number of people who will use the new product);

$\mathrm{N}(\mathrm{t}) \quad$ - total number of followers who accepted the innovation at a certain point in time (persons);

p - innovation ratio;

$\mathrm{k} \quad$ - simulation ratio;

$\mathrm{r} \quad-$ replication ratio.

According to Miliutina (2013b), the innovation ratio ( $p$ ) characterizes the first wave of diffusion of innovative TP into the market, i.e. its 
perception by "Super Leaders" (the first and partly the second sales season). The simulation ratio ( $\mathrm{k}$ ) indicates the share of TP consumers who first imitate the "Super Leaders" by copying of their behavior (the second and partly third, and later, respectively, the third and partly fourth sales seasons). Despite the crucial importance of these seasons, the total share of consumers involved is still quite small, and the TP remains new for the main part of the market. In other words, as the main portion of the market ("Leader-Followers", "Moderate Majority" and "Traditionalists") will become involved only after the successful completion of the first three-four seasons, we also used the replication ratio ( $r$ ) in the forecasting, making it possible to determine the share of these three groups of innovative TP consumers (Tab. 2). Without their involvement in the process of TP diffusion, and hence to the spread of positive information about it, it is impossible to turn the newly introduced TP into a popular (fashionable, "trendy") one.

As Table 2 shows, each of the selected segments differs not only in volume, but also in the pace and unanimity of both involvement and rejection of the perceived and already consumed TP. "Super Leaders," "Loyalists" and "Sympathetic" customers will immediately and fully respond to the TP on offer; however, their interest will last only for one season. That means, none of them will remain for the next season. So, if the "anchor" TA offers them another novelty next season, their "devotion" and "sympathy" for the TA will be in confidence in its innovation, and hence in their repurchase from this TA. However, given the psychographic characteristics (for example, the constant search for something unfamiliar), they will not be able to repurchase the same TP.

Super Leader finders will come $100 \%$ in the second season together with Loyalist leaders. However, if among the Leaders there are some who want (about 50\%) to buy the same TP again, the Super Leader finders will need something new for repurchasing.

Following of their more determined predecessors, approximately $80 \%$ of sympathetic Leaders, $60 \%$ of finder Leaders and $50 \%$ of loyal LeaderFollowers will buy in the third season. The difference between these groups is the greater mobility of the Leaders, who will more synchronously make purchasing decisions and stay for no more than two seasons. At the same time, the followers of the leaders will be involved in smaller groups and, provided that the quality of TP meets their expectations, they may remain even for as long as four seasons. 


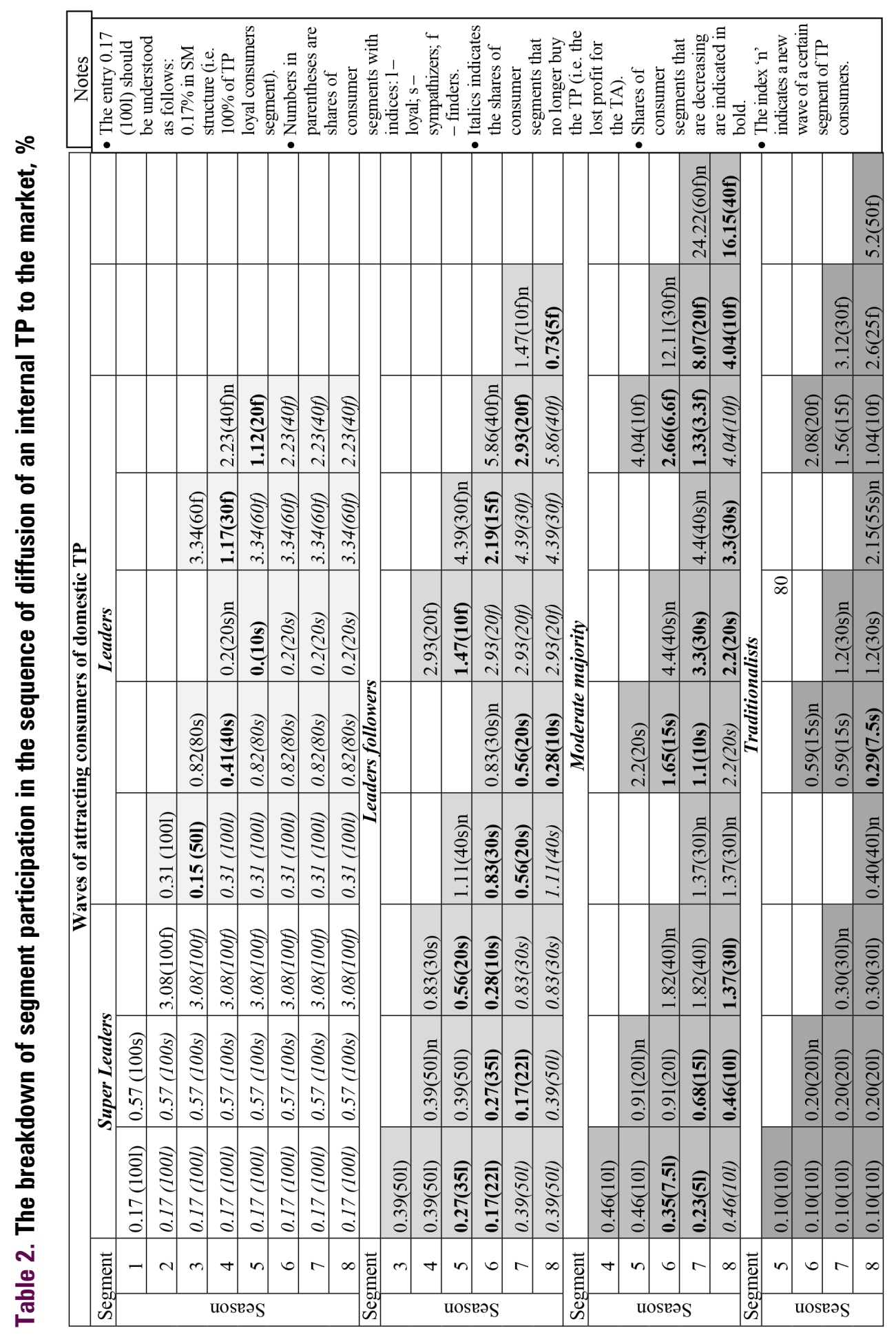

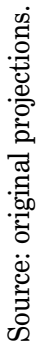


Starting with the fourth season, there will be an increasing diversity of TP consumer segments. At the same time, five subsegments will be interested in the product: $60 \%$ of sympathetic Leaders, $70 \%$ of finder Leaders, as well as all three subgroups of Leader-Followers - $100 \%$ loyal (half of which are those who have already consumed the TP in the third season and repurchase in full), $30 \%$ of sympathizers and $20 \%$ of finders.

By the fifth season, the number of subsegments will increase to nine. Leaders (of whom $10 \%$ will be sympathizers and $20 \%$ of finders) will be replaced by all three subgroups of Leader-Followers (of which at this stage will be dominated by loyalists - $85 \%$, sympathizers will be sufficiently represented $-60 \%$, and finders - 40\%). In addition, small shares of all three subsegments of the moderate majority and even $10 \%$ of traditionalists will dare to buy TP.

During the sixth season, nine subsegments will also buy the TP: three subgroups of Leader-Followers, moderates and traditionalists. That is, instead of Leaders (who will no longer be interested in this TP) there will be sympathizers and finders of the Traditionalists segment. The last point will indicate that TP is no longer perceived by the market as an innovation.

The seventh and eighth seasons show an increasing involvement of the Moderate Majority and Traditionalists Segments, with a gradual decrease in the share of all subsegments of Leader-Followers.

The proposed interpretation of the dynamics of the breakdown of segment participation in the diffusion of domestic and inbound TP into the market illustrates in detail the sequence and content of this process, which allows us to make certain important conclusions.

Firstly, the number of participants in each subsegment is a value equal to the measure used through the system used by the TA. According to our research, in modern conditions, the cooperative marketing system (Shulgina, 2005), which involves not only the development of relationships with the consumer, but also close cooperation with him or her, is the most effective. Cooperation in the "TA - consumer" system should involve encouraging the consumer to participate in the development of an individualized TP, developed "just 
for him". This can only happen on the basis of the transformation of formal relations between the $\mathrm{TE}$ employee and the client into friendly (informal) ones. It is especially important to warn against understanding informal communication with the client as being the same as familiar communication. This is a question of such close study of the consumer's needs and such a sincere desire to meet them, so that he or she gains a high level of trust in the TA and a desire to do business with it in the future.

Secondly, a detailed description of the sequence and depth of diffusion of a TP from a new perspective illustrates the need for TA employees to understand the impact of the product characteristics on consumer behavior. Recall that according to the model

developed in the 1980 s by Noriaki Kano, any product can be represented as a set of characteristics: mandatory (must-be), quantitative, unexpected, problematic and indifferent. The development of this theory is traced out in Motrynchuk (2014), where it is demonstrated how the unexpected characteristics of a TP (new to the consumer) in the next season become quantitative for him, and these, respectively, become mandatory. It follows that even Traditionalists will eventually expect a modification of the TP and a gradual improvement in its quality. More mobile segments will need more radical changes or new TPs. In other words, even in the implementation of a focus strategy for the TA, it should not focus on the proposals of only a single TP.

Thirdly, the waves show not only the involvement, but also the volume and structure of consumer losses by the company, which should be considered as lost profits for the TA. The data in Fig. 2 illustrates the dynamics, volume and structure of consumer segments by sales seasons.

Fig 2. illustration provides important information for adjusting the strategy and indicates the following.

1) Even with individualized marketing, the sale of a single TP (i.e., if there is insufficient choice for the consumer) leads to consumer losses (Tab. 3). 
告
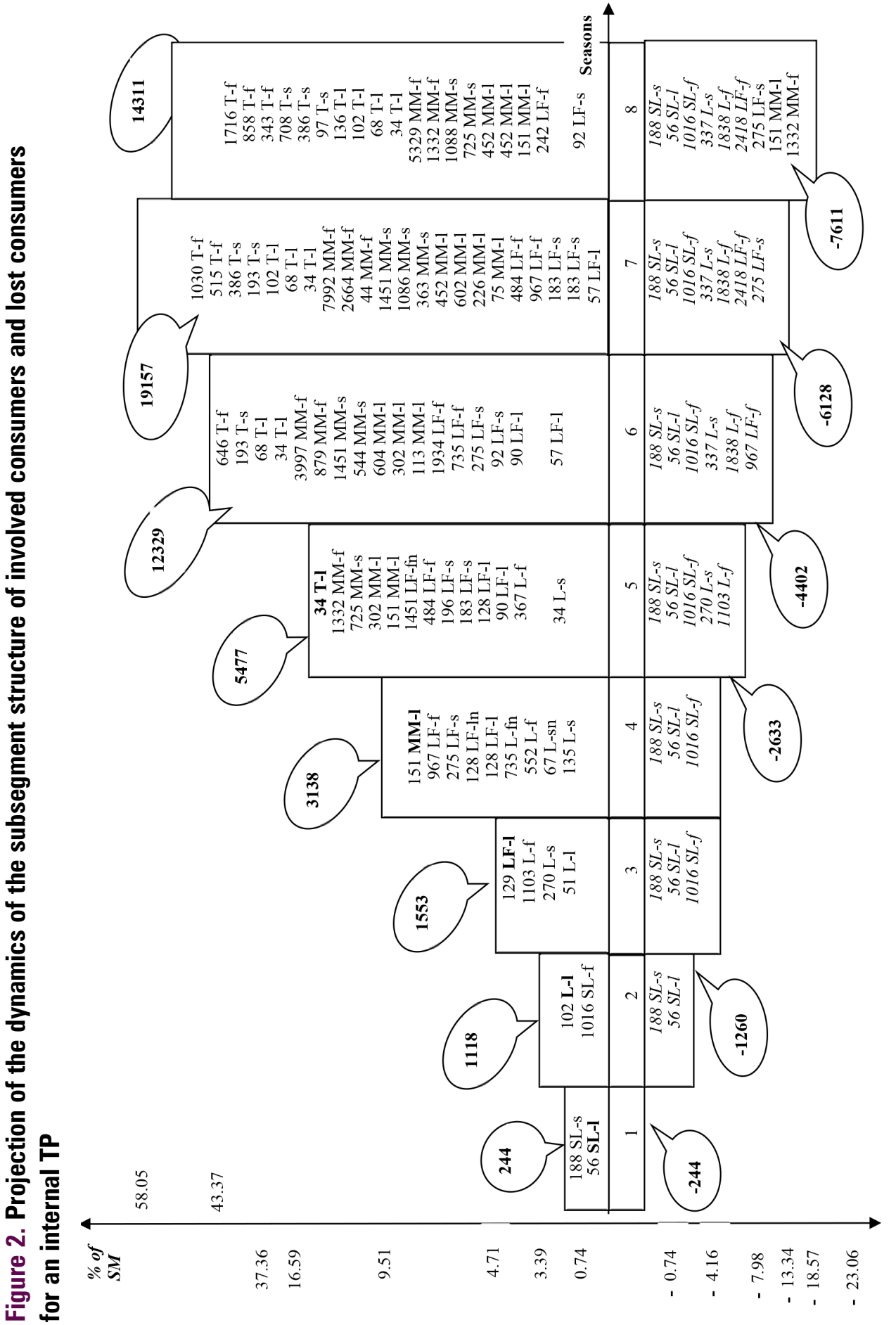

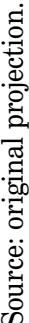


Table 3. Shares of lost customers for TA by seasons, \%

\begin{tabular}{l|c|c|c|c|c|c|c}
\hline \multirow{2}{*}{ Type of tourism } & \multicolumn{7}{|c}{ Seasons } \\
\cline { 2 - 8 } & $\mathbf{2}$ & $\mathbf{3}$ & $\mathbf{4}$ & $\mathbf{5}$ & $\mathbf{6}$ & $\mathbf{7}$ & $\mathbf{8}$ \\
\hline Internal & 17.9 & 44.8 & 28.6 & 32.5 & 26.3 & 24.2 & 34.7 \\
Inbound & 13.4 & 43.9 & 33.7 & 37.0 & 27.4 & 27.4 & 25.9 \\
\hline
\end{tabular}

Source: data on the basis of the author's research.

It is clear that the consumer always has the right to choose, and the TA cannot work without losses, however, these are losses that can and should be reduced.

2) If the derived TP is not modified at least in the fourth season, then there will be a noticeable decrease in sales growth in the seventh season, and its decline will begin in the eighth one.

Fourthly, given the different composition of consumers during the described seasons, each season will require not only a modified TP, but also, due to this, different composition differences in all elements of the TP. Special attention will need to be paid to the complex of marketing communications, which is being improved most intensively, offering new tools and approaches almost every year. As for evidence in support of the notation that the share of consumers is dependent upon on the availability of quantitative choice in the range of TP, we found that the signs of the trend (to reduce of sales growth in the seventh season and the beginning of the decline in the eighth) begin to decrease with a choice of two TPs. Also, if the number of differentiated positions is increased to seven TPs they ultimately disappear.

\section{Conclusions}

Based on the analysis of theories of product life cycle and consumer behavior, we formulated important starting points for forecasting of the introduction of an innovative tourist product: the company will be interested in reducing the stage of "Product Introduction", i.e. in making a faster transition to the stage of "Growth"; given such indicators on 
structural elements of the target market as the degree of commitment to tourist agencies and tourist products, as well as the attitude of consumers to innovative tourist products, the expected sales of the "anchor" tourist agency can be determined; the level of consumer commitment to the tourist agency (and hence to their tourist products) can be measured and, if necessary, adjusted with the help of marketing tools, regulating both the structure of the target market and its activity in tourist product purchasing.

From the point of view of the need to implement a focusing strategy, the characteristics of consumers in the "Serviced Market" subsegments have been clarified: the probability of a positive perception of tourist products by other segments depends much more on the segments of "Super Leaders" and "Leaders" in tourism (as compared to other industries). The segment of the "Loyalists Market" is the smallest, and it is the most difficult to cultivate and maintain. So, to create a kind of "reserve" to replenish it, it is necessary to constantly work on expanding the groups of the "Sympathizers Market" and "Finders Market". The volume of the most unstable segment, the "Finders Market", significantly exceeds the size of other segments and largely depends on the psychographic characteristics of its participants. The segment of "Traditionalists" is relatively small. However, it is almost comparable in number to the segment of "LeaderFollowers" (which significantly affect the perception of tourist products by the market) and "Traditionalists" significantly outperform the "LeaderFollowers" in terms of demand and commitment to established priorities.

Based on the models that describe the diffusion of new tourist products, as well as our established boundaries of the target and serviced markets, we determined the composition and structure of participation of each subsegment in the sequence of diffusion of domestic and inbound tourist product to the market. On this basis, it was demonstrated that the number of participants in each subsegment is a value that largely depends on the system of attraction used by the tourist agency (yet another argument in favor of developing a cooperative marketing system). In terms of new aspects of the work herein, we illustrated the need for employees of tourist agency to understand the impact of product characteristics on consumers behavior, as well as the rules of transition of types of characteristics from 
lower to higher level. Also, the number of tourist agency consumers lost due to a lack of choice of tourist products was calculated.

Overall, the original forecasting methodology presented herein, based on the concept of product life cycle and the theory of consumer behavior, has been demonstrated as useful for calculating the sales volumes of an innovative product in the tourist industry as well as the rate of its penetration into the market. Moreover, this methodology has been empirically confirmed based on data from a questionnaire survey on the domestic tourism market among high school and university students in the region of Vinnytsiya, Ukraine. In general, such a refined methodology, employing deep market segmentation take into account the behavioral peculiarities of individual subsegments and the flows between them, is all the more necessary in many markets and industries, especially in today's shifting economic circumstances.

\section{References}

1. Balashova, R., Ivchenko, L. (2011). Metodychni zasady analizu ta prognozuvannia rynku turystychnyck posług $\mathrm{v}$ Ukraini $\mathrm{z}$ vykorystanniam matematychnogo modeliuvannia [Methodical bases of analysis and forecasting of the market of tourist services in Ukraine with use of mathematical modeling]. Ekonomika, 3(110), 3-9. http://dspace.nbuv. gov.ua/bitstream/handle/123456789/33699/01-Balashova.pdf

2. Bass, F. M. (2014). Diffusion model ?stimation using adaptive nonlinear least squares: Multiple generation algorithm NL2SOL. Working Paper, Bass Economics: Glenmoor Court, Frisco.

3. Dedu, V. K., \& Saforo, F. K., (2016). Prediction of stock performance on the Ghana stock exchange using financial ratios: A logistic regression approach. International Journal of Scientific Research and Management, 4(6). https://ijsrm.in/index.php/ijsrm/ article/view/364

4. Global Business Travel Market Size, Trends and Insights. (2020 Edition). https://www.reportlinker.com/p05876245/Global-Business-Travel-Market-Size-Trendsand-Insights-Edition.html

5. GUS (2014, 2015, 2016, 2019). Golovne upravlinnia statystyky u Vinnytskiy oblasti. [Main Department of Statistics in Vinnytsia Region. Official website]. http://www.vn.ukrstat.gov.ua/index.php

6. Husain, S., Ghufran, A., \& Chaubey, D. (2016). Customers' behavior towards social media marketing: An empirical study. ZENITH International Journal of Business Economics \& Management Research, 6(8), 58-68. http://www.indianjournals. com/ijor.aspx?target $=$ ijor:zijbemr\&volume $=6 \&$ issue $=8 \&$ article $=007$ 
7. Kirkova, N. P. (2014). Prognozuvannia osnovnyck tendenciy rozvytku turystychnoyi galuzi Ukrainy [Prediction of major trends of the tourism industry developments in Ukraine]. Efektyuna Ekonomika, 7. http://www.economy.nayka.com.ua/?op=1\&z=3197

8. Miliutina, Yu. (2013a). Prognozuvannia tempiv ta obsiagiv vyvedenia na rynok innovacijnogo turystychnogo produktu [Forecasting the rate and volume of innovative tourist product introduction to the market]. Naukovi Studii, 21(2), 652-666, https://elibrary.ru/item.asp?id=24292105

9. Miliutina, Yu. (2013b). Marketing innovetsiy turystychnogo pidprijemstva [Marketing of innovations of the tourist enterprise]. Avtoreferat kandydatskoyi dysertacii, Kyiv, Kyivskyy Natsionalnyy Torgovelno-Ekonomichnyy Universytet.

10. Motrynchuk, O. (2014). Metod Kano jak odyn $z$ instrumentiv otsinky stupenia zadovolenosti spozhyvacha [The Kano method as one of the tools for assessing the degree of consumer satisfaction]. http//www.irbis-nbuv.gov.ua

11. Shulgina, L. (2005). Marketing pidpryjemstv turystychnogo biznesu: Monografiia [Marketing of tourism business enterprises: Monograph]. Kyiv, Kyivskyy Natsionalnyy Torgovelno-Ekonomichnyy Universytet,

12. Shulgina, L., \& Onishchuk, N. (2016). Systema marketingu spivpraci: Teoriia, metodologiia ta praktyka. Monografiia [Cooperative marketing system: Theory, methodology and practice. Monograph]. Kyiv: "MP Lesia".

13. Szulgina, L., \& Miliutina, Ju. (2014). Issledovanie innovatsyonnykh marketingovykh instrumentov [Researching innovative marketing tools]. In I. Dudzik-Lewicka, H. Howaniec, J. Klisiński, W. Waszkielewicz (Eds.) Potencjat intelektualny $i$ innowacyjny $w$ zarzadzaniu organizacja (Chapter 6, pp. 49-67). Bielsko-Biała: Wydawnictwo Naukowe Akademii Techniczno-Humanistycznej.

14. Vinnitsia City Council. (2019). Tourism - Analityka ta statystyka galuzi turyzmu. Vinnytska mis'ka rada. Ofitsijnyy veb-sait. [Tourism - Analytics and statistics in the field of tourism. Vinnytsia City Council. Official website]. https://www.vmr. gov.ua/Branches/Lists/Tourism/ShowContent.aspx?ID=2

15. Wozniak, T., Schaffner, D., Stanoevska-Slabeva, K., \& Lenz-Kesekamp, V. (2018). Psychological antecedents of mobile consumer behaviour and implications for customer journeys in tourism. Information Technology \& Tourism, 18, 85-112. https://link. springer.com/article/10.1007/s40558-017-0101-8

Liudmyla Shulhina - Doctor of Economics, Professor of Economics, University of Finance and Law, BielskoBiala, Poland. The author of 321 publications (215 scientific and 106 educational-methodical), of which 3 monographs were published in Poland, 8 monographs by 2-3 authors in Ukraine, and 34 articles in scientific publications in various countries (Poland, Estonia, Russia, Belarus, Slovakia, Bulgaria, Czech Republic). She has published 21 articles in English, 9 in Polish and 4 in Russian. She served as supervisor for 8 doctoral studentswho successfully defended their theses. She is the academic Coordinator of the Project "European business models: transformation, harmonization and implementation in Ukraine", no. 587138-EPP-1-2017-1-UA-EPPJMO-MODULE. 